\title{
NEW HISTORICISM ANALYSIS IN SENSE AND SENSIBILITY NOVEL BY JANE AUSTEN
}

\author{
Fitrianita Febrina Ali ${ }^{1}$ \\ Universitas Muhammadiyah Gorontalo \\ febrinaali99@gmail.com \\ Moon Hidayati Otoluwa ${ }^{2}$ \\ Universitas Negeri Gorontalo \\ otoluwamoonhidayati@gmail.com
}

\begin{abstract}
This study focused on the use Stephen Greenblatt theory to analyze the novel "Sense and Sensibility" by Jane Austen. This study aims to determine the aspects of the novel by using New Historicism approach. The method used in this research is descriptive qualitative. The data used is written data and the technique used is reading notes. Based on the results of the data analysis, researcher found several context of New Historicism in the "Sense and Sensibility", namely historical context, social context, cultural context, and biographical context. Historical context to find out how historical factors contained in the novel are then compared to non-literary texts in that era. Social context to find out how the social situation at that time. Cultural context to find out how the culture of society at that time, and biographical context to compare whether the novel describes the life of Jane Austen in the real life.
\end{abstract}

Keywords: New Historicism, Novel, Sense and Sensibility.

\section{INTRODUCTION}

New historicism is literary criticism related to the historical, social, and cultural context of the writer at the time the literary work was produced. Seen from the time, place, and historical circumstances of the author. In addition, this literary critic assumes that a literary critic must understand the history of the author to analyze the literary text. New historicism adherents believe that themes and characterizations in each literary text develop due to the influence of social conditions in their time. In addition, literary works are also the work of humans and the results of history(Bano et al., 2005).

The word New historicism was first used by Stephen Greenblatt in an introduction to the edition of the journal Genre in 1982, to offer a new perspective in the study of the Renaissance, namely by emphasizing the relevance of literary texts to the various social, economic and political forces that surround them. (Emphasizing the relationship between literary texts and non-literary texts.

\section{British, Jurnal Bahasa dan Sastra Inggris}


Literature, according to New Historicism is inseparable from social, political, and economic praxis because it is a part of literature. From this, the separation between extrinsic and intrinsic can no longer be maintained. Because all texts are the same, both literary and non-literary, is a power struggle from ideology (Budianta, 2006a).

This means that history or the world referred to by literary works, not only become an integral and unified background in the text, but history itself is composed of various kinds of texts that make up reality according to their respective versions of the authors. New Historicism views historical reports as narrative, as stories, which are usually not normally avoided from the point of view of those who wrote them. In the thought of new historicism, historical facts are not absolutely indisputable, because history itself consists of various versions that are full of contradictions, plurality and very various underlying motives. Based on the above quotation the relationship between literature and history is the intertextuality linkage between various kinds of texts both fiction and factual produced at the same time and at different periods of time (Budianta, 2006b).

A simple definition of New Historicism is its method based on the process of studying in parallel literary and non-literary texts. This means that New Historicism compares literary texts with non-literary texts (Berghahn, 1992). In conventions traditionally, a work both prose and poetry is understood as a literary text which is understood as a literary text that contains events and also the life of history. While the purpose of history in general view is directed to the past written by historians (Munslow, 2018).

Jane Austen is a very important woman writer in the Georgian era. She works with a lot of themes about women in her era, and very popular until now. The theme that is often raised and very dominant in her works is marriage. She illustrates that in her era, marriages of different social status were very limited and difficult to realize. Someone from the upper class, generally only marry someone from their own class. This was done because it was to strengthen the dynasty, gather wealth, land and inheritance. Therefore, the aspects contained in Austen's 
work are not only about romance, but sociological aspects are so dominant in her time.

Sense and Sensibility tells about how Elinor and Marianne, the two girls of the Dashwood family who have entered the age of being ready to marry must face the intrigues of 18th century life in England which are very thick with nuances of marriage, inheritance, and social life that are vulnerable to scandal and must always be perfect in people's eyes. At that time a person's honor is valued form wealth, high position that is often passed down from generation to generation (Miller, 2017).

\section{RESEARCH METHOD}

The method used in this research is descriptive qualitative method. Descriptive method is a method of research to examine the status of an object, a condition, a system of thought, an event or status of a grup of men. In this case the authors analyze how the historical aspect in the text of the novel "Sense and Sensibility" by Jane Austen. Sources of the data in this study include the source of primary data and secondary data. The primary data source is a source that directly provide data to researchers. The primary data source in this case is the text of the novel Sense and Sensibility by Jane Austen. While secondary data or supporting data in this case, namely books, articles and journals that discuss historical, social, cultural, and biographical aspects. Data documentation is a technique for collecting the data by using evidence, detailed information from sources such as the primary source and a secondary source. Novel including the main source that will be analyzes, whereas a secondary source research over the journals and articles (Creswell et al., 2007). In this research, the researcher also applies the New Historicism approach for is one of the methodologies used to study literary texts specially those which have links to their outside contexts. It is a theory proposed by Stephen Greenblatt in the twentieth-century and its main tenet is the interpretation of literature in terms of the milieu from which it emerged.

\section{British, Jurnal Bahasa dan Sastra Inggris}




\section{RESEARCH FINDING AND DISCUSSION}

\section{New Historicism}

The researcher applied the New Historicism aspect in novel Sense and Sensibiliy by Jane Austen. There are the historical context, the social context, the cultural context, and the biographical context.

\section{The Historical context}

Historical context is an important aspect in knowing the origin of literary works. We can find out what underlies the work of literature was made by looking at the history behind the literary work. We can also examine whether the events contained in the work actually happened in his era or not by comparing literary texts with non-literary texts. From the following data, I found historical facts in the novel Sense and Sensibility, that in the Georgian era literary works that were written contained a lot of romantic elements.

Data 01

'Does your sister make no distinction in her objections against a second attachment? Or is it equally criminal in everybody? Are those who have been disappointed in their first choice, whether from the inconstancy of its object, or the perverseness of circumstances, to be equally indifferent during the rest of their lives?' (Page 43)

From data 01 illustrate that this novel contains elements of romance, because the situation illustrates that, Colonel Brandon talks to Elinor about Marriane who does not believe in people who fall in love more than once in his life. It shows that Austen novel Colonel Brandon loved Marriane very much. This proves that Jane Austen's novels portray romantic literature in the Georgian era.

Data 02

But Elinor-how are HER feelings to be described?- From the moment of learning that Lucy was married to another, that Edward was free, to the moment of his justifying the hopes which had so instantly followed, she was everything by turns but tranquil. But when the second moment had passed, when she found every doubt, every solicitude removed, compared her situation with what so lately it had been,-saw him honorably released from his former engagement, saw him instantly profiting by the release, to address herself and declare an affection as tender, as constant as she had ever supposed it to be,- - she was

\section{British, Jurnal Bahasa dan Sastra Inggris}


oppressed, she was overcome by her own felicity; - and happily disposed as is the human mind to be easily familiarized with any change for the better, it required several hours to give sedateness to her spirits, or any degree of tranquility to her heart. (Page 271)

Data 02 describes the situation where Edward came to Elinor and reported canceling his engagement with Lucy. Lucy canceled her engagement with Edward and married Mr. Robbert Ferrars, the younger brother of Edward Ferrars. This is a miracle for Edward and Elinor's relationship, because they really love each other. However, because Edward had already been engaged to Lucy, so he could not express his feelings to Elinor. Edward finally unhesitatingly expressed his feelings to Elinor and invited her to marry.

Data 03

Colonel Brandon was now as happy, as all those who best loved him, believed he deserved to be; - in Marianne he was consoled for every past affliction;-her regard and her society restored his mind to animation, and his spirits to cheerfulness; and that Marianne found her own happiness in $f$ orming his, was equally the persuasion and delight of each observing friend. Marianne could never love by halves; and her whole heart became, in time, as much devoted to her husband, as it had once been to Willoughby. (Page 283-284)

Data 03 illustrates the happiness of Colonel Brandon because eventually Marriane accepted his love. Marriane who previously loved Willoughby and finally broke his heart because Willoughby married someone else because of property. Marriane finally realized that Colonel Brandon had been accepting him for what he was, concern for him and had sacrificed a lot for him, so Marriane received Colonel Brandon's love and married him. Colonel Brandon and Marriane now get happiness after marriage. Marriane slowly loves and presents her whole heart to Colonel Brandon as he once loved Willoughby.

From data 01-03, it can be concluded that the novel Sense and Sensibility describe The Georgian era. Where austen was born. This era is also called the transition period, where the beginning of the industrial revolution, led to a shift in the trend of enlightment to romantic trends in literary works. Austen was also more interested in describing daily life during this period in his fictional character. The Georgian era was also marked by people who used letters for long-distance communication tools.

\section{British, Jurnal Bahasa dan Sastra Inggris}




\section{The Social Context}

Social context in literary works is how social life in the time of literary works was written. In these data, it is described how the social context in the Georgian era.

'Nay, my dear, I'm sure I don't pretend to say that there an't. I'm sure there's a vast many smart beaux in Exeter; but you know, how could I tell what smart beaux there might be about Norland; and I was only afraid the Miss Dashwoods might find it dull at Barton, if they had not so many as they used to have. But perhaps you young ladies may not care about the beaux, and had as lief be without them as with them. For my part, I think they are vastly agreeable, provided they dress smart and behave civil. But I can't bear to see them dirty and nasty. Now there's Mr. Rose at Exeter, a prodigious smart young man, quite a beau, clerk to Mr. Simpson, you know, and yet if you do but meet him of a morning, he is not fit to be seen.-I suppose your brother was quite a beau, Miss Dashwood, before he married, as he was so rich?' (Page 93)

From data 04 Miss Stele explained about her type of ideal man. He gives opinions about men who can be classified as good are those who dress well and behave politely. He also asked about Miss Dashwood's cool brother before marriage because he was rich. Social aspect shows, from the conversation between Miss Steele and Miss Dashwood. Miss Steele, asked curiously about whether they were not sad after moving from Norland. Elinor felt that the question really sounded like a satire, according to him the tone of the question posed by Miss Stele was not polite for someone who just knew. But miss stele doesn't care and asks other questions, about how many cool men live in Barton. He thinks there aren't many cool and rich men in Barton. He really humbled Miss Dashwood's residence.

This illustrates, how important most English women in the Georgian era in general, who want to increase their social status by looking for rich men. The life and well-being of women as dependent on men. So they will look for men who are handsome, rich, and from families with high social status.

Data 05

I have no doubt in the world of your faithfully keeping this secret, because you must know of what importance it is to us, not to have it reach his mother; for she

\section{British, Jurnal Bahasa dan Sastra Inggris}


would never approve of it, I dare say. I shall have no fortune, and I fancy she is an exceeding proud woman.' (Page 99)

Data 06

If in the supposition of his seeking to marry herself, his difficulties from his mother had seemed great, how much greater were they now likely to be, when the object of his engagement was undoubtedly inferior in connections, and probably inferior in fortune to herself. These difficulties, indeed, with a heart so alienated from Lucy, might not press very hard upon his patience; but melancholy was the state of the person by whom the expectation of family opposition and unkindness, could be felt as a relief! (Page 103)

Data 05-06 dialog between Lucy and Elinor. In this dialog, Lucy tells to Elinor that she is engaged to Edward. They kept it a secret from the Edward family because Lucy was not rich and came from lower class. Data 05 explain that Edward's mother is likely not going to agree with Edward's engagement with Lucy because her fiance is not from a respected family. From data 05 untill data 06 illustrate that some women in the georgian era who came from the middle class or lower class, tried to improve their social status, by marrying a wealthy man. Men who have high social status, have a lot of inheritance, come from respectable families, and are handsome are the ideal type of women in the georgian era. Simply explain that social class is a major concern in choosing prospective wives or prospective husbands in the Georgian era. People who come from wealthy families, usually will not allow their children to marry someone from a lower social status. They want their child's husband or wife, at least equal or richer than them.

\section{The Culture Context}

The cultural context refers to 'way of life' involving religion, race, and nationality, as well as things like food, dress code and manners.

Data 07

Marianne's abilities were, in many respects, quite equal to Elinor's. She was sensible and clever; but eager in everything: her sorrows, her joys, could have no moderation. She was generous, amiable, interesting: she was everything but prudent. The resemblance between her and her mother was strikingly great. (Page 6)

\section{British, Jurnal Bahasa dan Sastra Inggris}


Data 07 described that Marriane is someone who is very sensitive to something. She is cheerful, smart, always passionate about everything, friendly, interesting and wise. Nature he got from her mother. This data illustrates morals which are aspects of culture according to.

\section{Data 08}

'No taste for drawing!' replied Elinor, 'why should you think so? He does not draw himself, indeed, but he has great pleasure in seeing the performances of other people, and I assure you he is by no means deficient in natural taste, though he has not had opportunities of improving it. Had he ever been in the way of learning, I think he would have drawn very well. He distrusts his own judgment in such matters so much, that he is always unwilling to give his opinion on any picture; but he has an innate propriety and simplicity of taste, which in general direct him perfectly right.' (Page 15)

Data 09

...And besides all this, I am afraid, Mamma, he has no real taste. Music seems scarcely to attract him, and though he admires Elinor's drawings very much, it is not the admiration of a person who can understand their worth. It is evident, in spite of his frequent attention to her while she draws, that in fact he knows nothing of the matter. He admires as a lover, not as a connoisseur. (Page 14)

Data 07-09 illustrated that in the opinion of people in the Georgian era, someone is very important to have a good taste of art. In Marianne's language, Edward lacks fire and the spirit In addition to Edward's lack of physical grace, he does not act like a lover with Elinor. His passionless temperament is further illustrated in his attitude to literature and to matters of 'taste' generally. When set by Marianne to read Cowper, he was, as she complains to her mother, tame and spiritless:

\section{Data 10}

'To hear those beautiful lines which have frequently almost driven me wild, pronounced with such impenetrable coldness, such dreadful indifference!-'

\section{Data 11}

'He would certainly have done more justice to simple and elegant prose. I thought so at the time; but you would give him Cowper.'

\section{Data 12}

'Nay, Mama, if he is not to be animated by Cowper!- but we must allow for difference of taste. Elinor has not my feelings, and therefore she may overlook it,

\section{British, Jurnal Bahasa dan Sastra Inggris}


and be happy with him. But it would have broken my heart had I loved him, to hear him read with so little sensibility!'

Further, this lover of her sister is endowed with sense, goodness, and every qualification which renders a man amiable, except that he could not read Cowper and jump through the ceiling with the violence of his feelings. He thinks, that a person might fall in love more than once in his life, which Marianne holds an utter impossibility. Edward's objective approach to art resembles Elinor's way of evaluating him. She knows enough of his background to see beyond the defects of his manner to the enduring qualities of his mind and spirit, his 'sense' and 'goodness,' and both these words imply that Edward's virtues are those of a given code of value, namely the Christian code.

Edward's character, Edward's aesthetic opinions, and Elinor's method of assessing Edward, all have this much in common - that they are based on prescribed standards, not on subjective impulse. Edward Ferrars is Elinor's own choice and he is Elinor's equal in right thinking, high principle, and properly regulated sensibility. Elinor often assures her dubious sister that he is an intelligent and upright young man, that 'his mind is well-informed, his enjoyment of books exceedingly great, his imagination lively, his observation just and correct, and his taste delicate and pure.'

Culturally, the Georgian era was characterized by the emergence of the novel and the discussion about whether it was a literary quality. The renaissance of the novel is linked to the emergence of the middle class, which, unlike the nobility, had not been brought up with the classics, not know Latin or Greek nor shared interest in issues of classical literature. Another important factor is that the printing press made it possible for the purchase of books was not accessible to the wealthy classes. The number of books published increased, allowing an increase in the number of professional writers. In other words, a new type of readers led to a new kind of writing.

\section{Biographical Context}

Biographical context is the biographical context contained in literary works. The author is usually inspired by his personal life in writing his literary 
works. Meanwhile, the researcher found the data that constitute the biographical context in the novel sense and sensibility.

\section{Data 13}

Mr. Dashwood's disappointment was, at first, severe; but his temper was cheerful and sanguine; and he might reasonably hope to live many years, and by living economically, lay by a considerable sum from the produce of an estate already large, and capable of almost immediate improvement. But the fortune, which had been so tardy in coming, was his only one twelvemonth. He survived his uncle no longer; and ten thousand pounds, including the late legacies, was all that remained for his widow and daughters. (Page 4)

Data 13 explain that Mr. Dashwood, father of Elinor and Marriane, died. This is the same as the life of Jane Austen whose her father also died. In 1807, the father of Jane Austen died. at that time, the church did not have provisions for widows and their children or families left behind. Therefore, Jane, Cassandra, and her mother experienced very severe financial difficulties. Although they have several older brothers, they can only donate annually which is $£ 50$ and their brother edward is $£ 100$. If not, it is very possible that they have to sacrifice their independence and work as governesses.

Data 14

As a house, Barton Cottage, though small, was comfortable and compact; but as a cottage it was defective, for the building was regular, the roof was tiled, the window shutters were not painted green, nor were the walls covered with honeysuckles. A narrow passage led directly through the house into the garden behind. On each side of the entrance was a sitting room, about sixteen feet square; and beyond them were the offices and the stairs. Four bed-rooms and two garrets formed the rest of the house. It had not been built many years and was in good repair. In comparison of Norland, it was poor and small indeed! but the tears which recollection called forth as they entered the house were soon dried away. (Page 22)

Data 14 illustrate that Mrs. Dashwood's and her three daughters moved to Borton cottage when her husband died. This story also illustrates the real life of Jane Austen. In 1801 the Austen family moved to Bath. They felt very sad and unhappy after their father died. At the end of 1807, Jane and her family moved to Southampton, where Jane felt much happier even though she could not continue her work as a writer. Finally, in 1809, their rich brother Edward, who had

\section{British, Jurnal Bahasa dan Sastra Inggris}


inherited three large estates of his adoptive parents, offered them a large cottage in one of his houses. Jane, Cassandra and her mother moved to the cottage in Chawton in July 1809. Jane regained her piano and practiced for an hour in the morning, on the cottage which was his home until his death in 1817 (Berkeley, 1998).

\section{Data 15}

I have formed my plan, and am determined to enter on a course of serious study. Our own library is too well known to me, to be resorted to for anything beyond mere amusement. But there are many works well worth reading at the Park; and there are others of more modern production which I know I can borrow of Colonel Brandon. By reading only six hours a-day, I shall gain in the course of twelve-month a great deal of instruction which I now feel myself to want.' (Page 256)

Data 15, illustrated that Marriane has a hobby for spending her leisure time for reading many books in their private library. In part of this novel, also describes the life of Jane Austen who has a hobby of reading and also has a library in her home. Jane's father who was a priest in the 18th century, George Austen, has a wide collection of books in his library. There are novels and comics there. His father will also read out quotes from Cowper and Crabble poems after every dinner. From an early age, Jane is a reader who is fluent in English and can also speak French and Italian. In her novels, it also appears that she loved the works of Shakespeare, Dr. Johnson, Fielding, and Richardson, who were literary gothic novels of the time (Austen, 1989).

\section{CONCLUTION AND SUGGESTION Conclusion}

The novel Sense and Sensibility is the romantic novel written by Jane Austen. The writer assumed that Jane Austen wrote the narrative of the novel were written based on her own situation happened in the Georgian Era from 1714 to 1830 , and the issues in this novel were written based on her own experience. The researcher analyzing the New Historicism that is concerned with the historical, social, cultural, and biographical of the author in the period of the time

\section{British, Jurnal Bahasa dan Sastra Inggris}


her literary work is produced of the time, place and historical circumstances of the author.

Through this novel, Jane Austen wanted to show British life at the time. How the historical, social, and culture, to describe the personality of the character of Elinor and Marriane. The two girls of the Dashwood family who have entered the age of being ready to marry must face the intrigues of $18^{\text {th }}$ century life in England, which are very thick with the nuances of marriage, inheritage, and social life that are valnerable to scandal and must always be perfect in people's eyes.

\section{Suggestion}

The researacher proposed some suggestions as follow:

a) For the reader

The story shows the reader that, at the time a person's honor is valued form wealth, high position that is often passed down from generation to generation. In Sense and Sensibility novel, Elinor even says that she does not have a large interest in marr iage. When looking at how important marriage was to social standing. However, knowing this, Austen again uses it to solidify her desire for society. By understanding what it was like during the late 1700s and early 1800s, the reader is able to better understand the importance of Austen's writings.

b) For the next researcher

Researchers hope this research can be useful for future researchers, although there are still many shortcomings in the results of this study. There are several aspects in this novel sense and sensibility that can be studied by subsequent researchers, that is feminism and social status, because these two aspects are very dominant in this novel. Hopefully the next researcher can do better research.

\section{REFERENCES}

Austen -Leigh, William and Austen-Leigh, Richard Arthur. 1986. Jane Austen: A Family Record, rev, Deirdre Le Faye. London: British Library.

Bano, D., Young, K. W., Guerin, C. J., LeFeuvre, R., Rothwell, N. J., Naldini, L., Rizzuto, R., Carafoli, E., \& Nicotera, P. (2005). Cleavage of the plasma membrane $\mathrm{Na}+/ \mathrm{Ca} 2+$ exchanger in excitotoxicity. Cell, 120(2), 275-285.

Berghahn, K. L. (1992). New historicism: Editorial introduction. Monatshefte, 
84(2), 141-147.

Budianta, Melani. 2002. In the Margin of the capital: From Tjerita Boedjang Bingung to Si Doel Anak Sekolahan" dalam Keith Foulcher dan Tony Day (ed), Clearing a space: postcolonial Readings of Modern Indonesian Literature. Leiden: KITLV

Budianta, M. (2006a). Budaya, sejarah, dan pasar: New historicism dalam perkembangan kritik sastra.

Budianta, M. (2006b). Decentralizing engagements: Women and the democratization process in Indonesia. Signs: Journal of Women in Culture and Society, 31(4), 915-923.

Creswell, J. W., Hanson, W. E., Clark Plano, V. L., \& Morales, A. (2007). Qualitative research designs: Selection and implementation. The Counseling Psychologist, 35(2), 236-264.

Fathoni. 2013. New Historisme Grenblatt: Identifikasi dan Relevansi dalam Kritik Sastra dalam blog Fathoni.

Guerin, W and others. 2005. A Handbook of Critical Approaches to Literature. (5th edition). New York: Oxford University Press.

Miller, W. B. (2017). Lower class culture as a generating milieu of gang delinquency. Routledge.

Munslow, A. (2018). Narrative and history. Macmillan International Higher Education.

Lascelles, Mary. 1995. Jane Austen and Her Art. London:Athlone. 